\title{
RECALCITRANT CARBON AND NITROGEN IN AGRICULTURE SOILS WITH RESIDUE ACCUMULATION AND FERTILIZATION UNDER TROPICAL CONDITIONS
}

\author{
CARBONO RECALCITRANTE E NITROGÊNIO EM SOLOS COM ACUMULAÇÃO E \\ FERTILIZAÇÃO DE RESÍDUOS EM CONDIÇÕES TROPICAIS
}

\author{
Joseph Elias Rodrigues MIKHAEL ${ }^{1}$; Risely Ferraz ALMEIDA ${ }^{2}$; \\ Fernando de Oliveira FRANCO ${ }^{3}$; Roberta Oliveira CAMARGO ${ }^{4}$; Beno WENDLING ${ }^{4}$ \\ 1. Research Assistant at School of Plants, Environment and Soil Sciences - LSU, Baton Rouge, LA, USA. jmikha1 @1su.edu; 2. \\ Postdoctoral Researcher at Escola Superior de Agricultura "Luiz de Queiroz" - USP, Piracicaba, SP, Brazil; 3. Empresa de Pesquisa \\ Agropecuária de Minas Gerais, Unidade Oeste, Uberaba, MG, Brazil. 4. Instituto de Ciências Agrárias -UFU, Uberlândia, MG, Brazil
}

\begin{abstract}
Soil organic matter has a strong relation to total organic carbon, and about $85 \%$ of organic carbon consists of humic substances (HS), classified as humin (HU), humic (HA) and fulvic acids (FA), and denominated as recalcitrant carbon in soil. HS are formed by complex, heterogeneous and polydisperse molecules, which have significant influence on the soil physical and chemical characteristics. The study evaluates the hypothesis that agricultural soils treated with organic residues may present higher carbon stocks as presented in forest soils. The aim of this study was to evaluate alterations in recalcitrant carbon and nitrogen stocks in Oxisol (Forest - FL, unfertilized Brachiaria - UB, and fertilized Brachiaria - FB) and Cambisol (Forest - FC, Coastcross - CC, sugarcane - CA, and silage corn - SM) at surface $(0.0-0.1)$ and subsurface $(0.1-0.2 \mathrm{~m})$, in the Zona da Mata in Minas Gerais state, Brazil. Result shows that fertilization, low soil disturbance and residual removal promoted increase of $\mathrm{C}$ and $\mathrm{N}$ content in HS, being close to native forests. Both, carbon and nitrogen recalcitrant, presented reduction with soil depth. HU ranged from 10.5 to $16.7 \mathrm{~g} \mathrm{~kg}^{-1}$ and presented the highest concentration compared to FA and HA. In Oxisol, FL and FB presented the highest SH concentration and demonstrate the positive effect of fertilization on carbon stocks improving soil quality in well-managed and productive areas. While, In Cambisol, FC and CC presented higher carbon and nitrogen in HS, mainly for HU and HA fractions, and SM showed the lowest concentrations in all fractions. Our results suggest that soil managements with lower soil disturbance and residual removal promotes increasing of carbon and nitrogen in recalcitrant fraction, with concentration close to native forests. Pasture should be fertilized to improve recalcitrant carbon and nitrogen stocks, avoiding process of degradation in tropical soil. It is an important outcome due to high levels of degraded areas in Brazil caused by inadequate use of soil mainly with pasture.
\end{abstract}

KEYWORDS: Brachiaria pasture. Humin. Fulvic acid. Humic acid. Organic matter

\section{INTRODUCTION}

Soil organic matter (SOM) is considered a $\mathrm{C}$ reservoir in the terrestrial environment with concentration three times higher than the atmospheric (SMITH, 2012). SOM improves soil structure, fertility, and crop yields (PANETTIERI et al., 2017), as well as SOM affects soil density and porosity (ALMEIDA et al., 2014) and nutrient cycling and availability (COLLETO et al., 2015).

SOM play role on soil preservation, mitigating erosion, improving soil water infiltration and retention and stabilizing soil structure (STEVENSON, 1994). Therefore, management of SOM stock is the key to effective ecological intensification and sustainability (TSIAFOULI et al., 2015), promoting higher soil organism abundance and diversity (GARRATT et al., 2018).

The capacity of SOM stocks is intrinsic to the ecosystem and depends on several factors, such as vegetation structure and composition, rainfall regime, soil moisture, temperature and nutrient contents (STOCKMANN et al., 2013; SÁNCHEZGONZÁLEZ et al., 2017), as well as soil texture and mineralogy (ZINN et al., 2011).

SOM has positive and strong correlation to total organic carbon (TOC) (Blair et al., 1995; Stevenson, 1994), and about $85 \%$ of TOC consists of humic substances (HS), classified as humin and humic and fulvic acids (STEVENSON, 1994) and denominated as recalcitrant carbon in soil. HS are formed by complex, heterogeneous and polydisperse molecules, which have significant influence on the 
Recalcitrant carbon and nitrogen...

soil physical and chemical characteristics (SILVA et al., 2014).

HS stock can be used to understand evolution and degradation processes in soil, as well as support the conservation management system (CUNHA et al., 2001). Studies on these aspects should be encouraged to support mitigate global climate-change (SOLLINS et al., 2017) and identify where human factors are significantly contributing to carbon losses into the atmosphere (AKPA et al., 2016), as a soil sustainable indicator (SALTON et al., 2011).

According to Panettieri et al. (2017), changes on SOM dynamics under different land uses are still poor understood. Thus, incubation research and field trials are needed to compare the old and new SOM understanding (SMITH et al., 2018). New studies will help to develop alternative management practices to support the expected intensification of food production (PICCOLLO et al., 2018).

To test hypotheses that area in use of forest presents higher carbon stocks and is similar to agriculture use with residues accumulation on soil and fertilization, the aim of this study was to evaluate alterations in total and recalcitrant carbon and nitrogen stocks in Oxisol and Cambisol under
MIKHAEL, J. E. R. et al.

different uses and managements in the Zona da Mata.

\section{MATERIAL AND METHODS}

The study was carried out in areas belong to EMBRAPA Dairy, located in Coronel Pacheco, Minas Gerais, Brazil $\left(21^{\circ} 14^{\prime} \mathrm{S}\right.$ latitude; $43^{\circ} 15^{\prime} \mathrm{W}$ longitude; $435 \mathrm{~m}$ altitude). The climate is classified as Aw according to Koppen, with an average annual temperature and rainfall of $21^{\circ} \mathrm{C}$ and $1581 \mathrm{~mm}$, respectively.

The experiment tested three soil uses (Forest - FL, unfertilized Brachiaria - UB and fertilized Brachiaria - FB) in a Oxisol, and four soil uses (Forest - FC, Coastcross - CC, Sugarcane - SC and silage corn - SM) in alluvial Cambisol. Both soils, were tested at two layers $(0.0-0.1 \mathrm{~m}$ and $0.1-0.2$ $\mathrm{m})$, using four replicates.

In Oxisol, pasture was cultivated with Brachiaria sp. since 2003, and fertilized with nitrogen $(\mathrm{N})$, phosphorus $(\mathrm{P})$ and potassium $(\mathrm{K})$ using a dose of $250 \mathrm{~kg} \mathrm{ha}^{-1}$ of 20-05-20 every year, in fertilized treatment. This area was deforested in 1950 and angola grass (Panicum numidianum) was initially planted, succeeded in 1986 by elephant grass (Pennisetum purpureum) until 2002 (Table 1).

Table 1. In Oxisol, management and use history with Forest (FL), unfertilized brachiaria pasture (UB) and fertilized brachiaria pasture (FB) located in Coronel Pacheco, Brazil.

Soil use Soil use and management

FL

Secondary Atlantic Forest

UB

1950: Deforestation

1950 - 1985: Angola grass

1986 - 2011: Brachiaria pasture

FB

1950: Deforestation

1950 - 1988: Angola grass

1989 - 2002: Elephant grass

2003 - 2011: Brachiaria pasture

In Cambisol, area with Coastcross grass (Cynodon dactylon L.) was implemented in 1992, fertilized with $10 \mathrm{~kg} \mathrm{ha}^{-1}$ of 20-20-20 (N, P, and K). In 2002, this rate was changed to $1 \mathrm{Mg} \mathrm{ha}^{-1}$ of formulation 05-20-20, with the addition of $50 \mathrm{~kg} \mathrm{ha}^{-}$ ${ }^{1}$ of the $\mathrm{N}$ top dressed in summer. Liming was performed at the time of planting with $3 \mathrm{Mg} \mathrm{ha}^{-1}$ of limestone and following planting with $1 \mathrm{Mg} \mathrm{ha}^{-1}$ every two years. By 1979, this area had become mostly Angola grass without fertilizer management, which was succeeded in 1980 until 1982 with Oat (Avena strigosa) intercropped with ryegrass (Lolium multiflorum) under irrigated pasture management in winter.

Silage corn area has been established since 1986, before that angola grass without fertilization was then established until 1985, vegetable crop species up to 1973, and clearing performed in 1935. At sugarcane area (Saccarum offinarum L.) implementation was in 1990, which received fertilizer only up to the fifth year at a dose of $300 \mathrm{~kg}$ $\mathrm{ha}^{-1}$ of 8-30-16 with producing around $70 \mathrm{Mg} \mathrm{ha}^{-1}$ in the first four years and decreasing to $40 \mathrm{Mg} \mathrm{ha}^{-1}$ due to the lack of proper management. In the history of 
the area after deforestation in 1935, then Angola grass establishment until 1989 without a specific management. From 1983 to 1991 there was the implantation of summer grain corn (Table 2).

Table 2. In Cambisol, management and use history with Forest (FL), pasture with Coastcross (CC), sugarcane (SC) and silage corn (SM) located in Coronel Pacheco, Brazil.

\begin{tabular}{ll}
\hline Soil use & Soil use and management \\
\hline FC & Secondary Atlantic Forest \\
& 1935: Deforestation \\
& 1935 -1979: Angola grass \\
& 1980 - 1982: Pasture oats \\
& 1983 - 1991: Summer grain corn \\
& $1992-$ 2011: Coastcross \\
CC & $1935:$ Deforestation \\
& 1935 - 1989: Angola grass \\
& 1990 - 2011: Sugarcane cultivation \\
& $1935:$ Deforestation \\
SC & 1935 - 1973: Cultivation of vegetable \\
& species \\
& $1973-1985:$ Angola grass \\
SM & 1986 - 2011: Silage corn \\
\end{tabular}

\section{Variables determination and Statistical analysis}

Samples were collected in disturbed conditions at the surface $\left(\begin{array}{llll}0.0 & -0.1 & \mathrm{~m}\end{array}\right)$ and subsurface layers $(0.1-0.2 \mathrm{~m})$ and forwarded to the laboratory to determine total soil organic carbon TOC (YEOMANS; BREMNER, 1988) and total organic nitrogen - TON (TEDESCO et al., 1995). Humic substances were identified according to the technique of differential solubility, separating the fulvic acids (C-FA), humic acids (C-HA) and humin $(\mathrm{C}-\mathrm{HU})$ in accordance with International Humic Substances Society (Hayes et al., 1989; Yeomamns and Bremner, 1988). After HS fractionation, we determined the amount of $\mathrm{N}(\mathrm{N}-\mathrm{HS})$ in each of the fractions (C-HA, C-FA and C-HU) via sulfuric digestion with subsequent Kjeldahl distillation (TEDESCO et al., 1995). The variables were submitted to analysis of variance (ANOVA) by the F-Test and compared according to the Tukey-Test $(p<0.05)$.

\section{RESULT AND DISCUSSION}

\section{TOC and TON results}

TOC presented a variation between 1.2 to $3.3 \%$, decreasing at soil depth with higher difference at FC $( \pm 0.8 \%)$, following CC $( \pm 0.7 \%)$, Figure 1. TOC decrease with soil depth has been reported in various articles (COLLETO et al., 2015; ALMEIDA et al., 2014; SANTANA et al., 2011; PULROLNIK et al., 2009), with highest TOC in surface due to accumulation and decomposition of vegetal and animal materials (ROSCOE et al., 2006), which depending on quality and quantity of the residues to increase TOC in soil (ALMEIDA et al., 2016).

In Oxisol, FL and FB presented similar TOC stocks, varying between 2.6 and $2.7 \mathrm{~g} \mathrm{~kg}^{-1}$ (Figure 1). This similarity is due to soil fertilization and liming (at implantation), which contributes to better vegetative development of pasture and higher production of organic material deposited on the soil. It is interesting result and shows how important is soil fertilization in pasture, mainly in areas with high level of degradation.

Pôrto et al. (2009) and Santana et al. (2011) have observed similar TOC levels between pasture areas and native forest. Generally, Forest presents higher SOM and TOC levels compared to other vegetation coverage due to soil management with soil movement, promoting water erosion and increasing organic residue decomposition (JAKELAITIS et al., 2008; CUNHA et al., 2012).

In Cambisol, SM presented the lowest TOC in both layers, with variations from 1.2 to $1.4 \mathrm{~g} \mathrm{~kg}^{-1}$ TOC (Figure 1). It clearly is a result of soil intense management with tillage, which provides an increase in the oxidation of organic matter. On the other hand, CC even being agriculture area, resulted in the highest TOC, with an increase of $49 \%$ compared to SC at 0.0 - $0.1 \mathrm{~m}$ layer (Figure 1). 

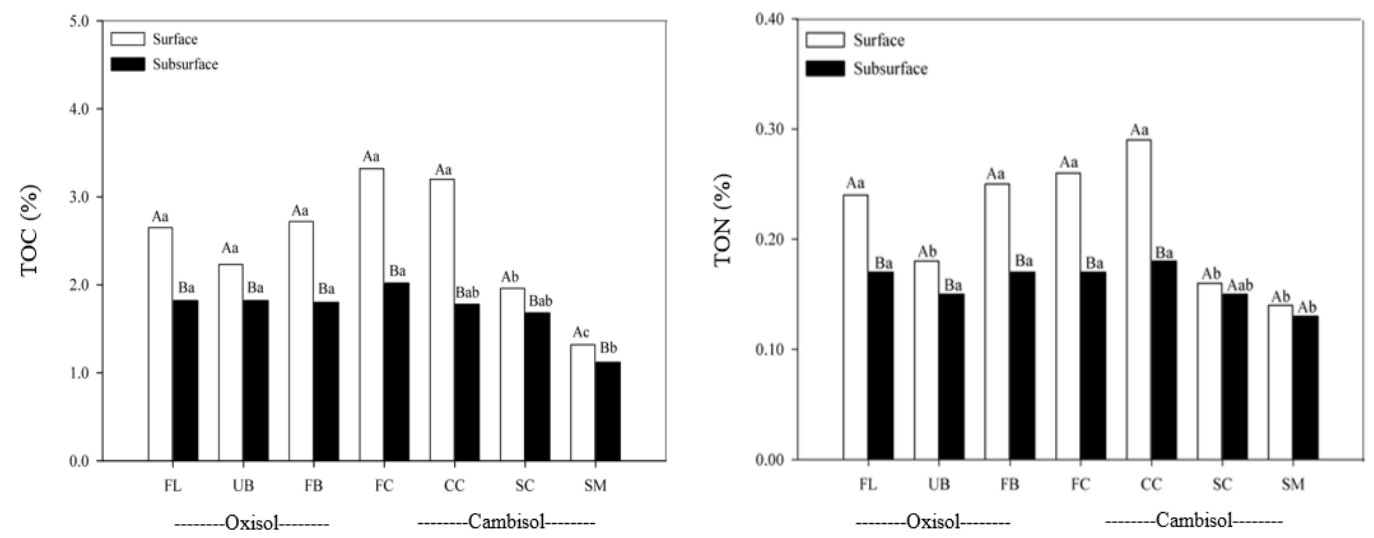

Figure 1. Total organic carbon (TOC; \%) and nitrogen (TON; \%) in a Oxysol (Forest - FL, unfertilized Brachiaria - UB and fertilized Brachiaria - FB) and Cambisol (Forest - FC, Coastcross - CC, Sugarcane - SC and silage corn - SM) at the surface $(0.0-0.1 \mathrm{~m})$ and subsurface $(0.1-0.2 \mathrm{~m})$. Bars identified with distinct lowercase letters (soil uses) and uppercase (layer) differ by the Tukey test ( $p$ $<0.05)$.

$\mathrm{CC}$ result was not expected is due to absence of soil tilling operations, which maintains the carbon physically protected from microbial attacks (STEVENSON, 1994). Neufeldt et al. (2002), Pulrolnek et al. (2009) and Almeida et al (2014) have reported similar results, and according to Jantalia et al. (2007), soil preparation has a negative effect on TOC stocks up to $30 \mathrm{~cm}$ deep in relation to the native Forest area.

TON was higher in the surface layer in all uses, with high relation to TOC accumulation (Figure 1) but was not possible to observe that relation on SM and SC (Figure 1). Probably, this uniformity at SM and SC between the layers is due to more intense and mechanized operations and the history of the cultivation (Table 2).

In Oxisol, there was higher TON at FL and FB as well observed to TON, with significant difference to UB at the surface layer (Figure 1). As well as, there was higher TON accumulation in FC and $\mathrm{CC}$ in Cambisol (Figure 1). The highest concentration of TOC and TON in FL and FC, was expected and is due to greater stability and less human intervention, which results in constant maintenance of plant residues and microorganisms responsible for mineralization. Generally, TON content is fall rapidly in soil cultivated with cereals, legumes and pasture due to $\mathrm{N}$ needs of microorganism (ALMEIDA et al., 2016; STEVENSON 1994).

\section{Humic Substance results}

$\mathrm{HU}$ ranged from 10.5 to $16.7 \mathrm{~g} \mathrm{~kg}^{-1}$ and presented the highest concentration compared to FA and HA (Table 3). This is a common outcome and has been presented by Assis et al. (2006), Rossi et al. (2011) and Martin et al. (2015). Generally, HU presents higher concentration due to strong resistance to microbial degradation and the strong association to soil mineral fraction, especially in oxide soil (STEVENSON, 1994). We can also point out that HU presents higher molecular size and greater degree of stability as characteristics. Therefore, FA and HA are less stable and can be polymerized or mineralized faster by soil microbial activity (FONTANA et al., 2006; VOLKOFF et al., 1978).

In Oxisol, FL and FB presented the highest humic substances concentration and demonstrate the positive effect of fertilization on carbon stocks improving soil quality in well-managed and productive areas. Higher $\mathrm{HU}$ and FA in soil also were found by Santana et al. (2011) comparing pasture with mineral fertilization and native pasture.

According to Martins et al. (2009), areas with brachiaria tends to present higher $\mathrm{HU}$ concentrations due to accumulation and decomposition of leaves and stems at the soil. Residues that presents high lignin content promote higher accumulation of $\mathrm{SH}$ in soil. HS presented higher $\mathrm{N}$ in surface with increases of $27 \%, 20 \%$ and $7 \%$ compared to subsurface, for the HU, HA, and FA, respectively (Table 3 ). 
Table 3. Carbon and nitrogen humic (HU), humic acids (HA) and fulvic acid (FA) in Cambisol (Forest - FL, pasture with Coastcross - CC, sugarcane - SC and silage corn - SM) at the surface (sur; $0.0-0.1 \mathrm{~m}$ ) and subsurface layer (sub; $0.1-0.2 \mathrm{~m}$ ).

\begin{tabular}{llllllll}
\hline & C-HU & \multicolumn{5}{c}{ C-HA } & \multicolumn{2}{c}{ C-FA } \\
\cline { 2 - 8 } FC & Sur & Sub & Sur & Sub & Sur & Sub & Mean \\
CC & $23.1 \mathrm{aA}$ & $12.3 \mathrm{abB}$ & $5.6 \mathrm{aA}$ & $2.5 \mathrm{aB}$ & 4.5 & 3.7 & $4.1 \mathrm{~A}$ \\
$\mathbf{C A}$ & $23.2 \mathrm{aA}$ & $9.7 \mathrm{bB}$ & $3.5 \mathrm{aA}$ & $2.1 \mathrm{aB}$ & 3.6 & 2.7 & $3.2 \mathrm{~b}$ \\
SM & $10.8 \mathrm{bA}$ & $9.8 \mathrm{bA}$ & $0.9 \mathrm{dA}$ & $0.7 \mathrm{bA}$ & 1.8 & 1.5 & $1.6 \mathrm{c}$ \\
\hline & N-HU & & N-HA & & & N-FA & \\
& Sur & Sub & Sur & Sub & Sur & Sub & Mean \\
FC & $1.5 \mathrm{bA}$ & $0.9 \mathrm{aB}$ & 0.8 & 0.5 & 0.4 & 0.3 & $0.3 \mathrm{~b}$ \\
CC & $2.1 \mathrm{aA}$ & $1.1 \mathrm{aB}$ & 0.7 & 0.5 & 1.1 & 1.0 & $1.1 \mathrm{~A}$ \\
CA & $0.9 \mathrm{cA}$ & $0.8 \mathrm{aA}$ & 0.5 & 0.4 & 0.5 & 0.4 & $0.5 \mathrm{~b}$ \\
SM & $0.9 \mathrm{cA}$ & $0.8 \mathrm{aA}$ & 0.3 & 0.3 & 0.2 & 0.2 & $0.2 \mathrm{~b}$
\end{tabular}

* Means following distinct lowercase letters in the column (soil layer) and the uppercase on the line (soil use) differ by the Tukey test ( $p$ $<0.05)$.

In Cambisol, FC and $\mathrm{CC}$ presented higher carbon and nitrogen in humic substances, mainly for HU and HA fractions. While, SM showed the lowest concentrations in all fractions (Table 3). According to Cunha et al. (2001), the FL presented this result because of the drastic and intrusive management with soil tillage, combined with the removal of the plant part (harvest) which contributes to the loss of soil quality by reducing the amount of C-HS.

According to Stevenson (1994) and Six et al. (2002), soil disturbance disrupts the aggregates, exposing the intra-aggregate $\mathrm{C}$, making the $\mathrm{C}$ more available to microbial attack and reducing the amount of carbon and nitrogen in HS.

\section{CONCLUSIONS}

Soil managements with lower soil disturbance and residual removal promotes increasing of carbon and nitrogen in recalcitrant fraction, with concentration close to native forests.

Pasture should be fertilized to improve carbon and stocks, avoiding process of degradation in tropical soil. It is an important outcome due to high levels of degradation areas in Brazil caused by inadequate use of soil mainly with pasture.

\section{ACKNOWLEDGEMENT}

The authors thank CAPES, FAPEMIG and Embrapa Gado de Leite for the support and encouragement of scientific production.

RESUMO: A matéria orgânica do solo tem uma forte relação com o carbono orgânico total, cerca de $85 \%$ do carbono orgânico é composto por substâncias húmicas (HS), classificadas como humina (HU), ácidos húmicos (HA) e fúlvicos (FA), denominadas como carbono recalcitrante no solo. As HS são formadas por moléculas complexas, heterogêneas e polidispersas, que exercem influência significativa nas características físicas e químicas do solo. O estudo avalia a hipótese de que solos agrícolas tratados com resíduos orgânicos podem apresentar maiores estoques de carbono como os encontrados em solos florestais. O objetivo deste trabalho foi avaliar as alterações nos estoques de carbono e nitrogênio recalcitrantes em Latossolo (Floresta FL, Brachiaria não fertilizada - UB, e Brachiaria fertilizada - FB) e Cambissolo (Floresta - FC, coastcross - CC, cana-de-açúcar e milho para silagem - SM) na superfície $(0,0$ - 0,1) e sub-superfície $(0,1-0,2 \mathrm{~m})$, na Zona da 
Mata em Minas Gerais, Brasil. Os resultados mostram que a adubação, a baixa perturbação do solo e a remoção dos resíduos promoveram aumento do teor de $\mathrm{C}$ e $\mathrm{N}$ na HS, estando próximos às florestas nativas. Ambos, carbono e nitrogênio recalcitrantes, apresentaram redução com a profundidade do solo. A HU variou de 10,5 a $16,7 \mathrm{~g} \mathrm{~kg}^{-1}$ e apresentou a maior concentração em relação à FA e HA. Em Latossolo, FL e FB apresentaram a maior concentração de SH e demonstraram o efeito positivo da adubação nos estoques de carbono, melhorando a qualidade do solo em áreas bem manejadas e produtivas. Enquanto, no Cambissolo, FC e CC apresentaram maiores teores de carbono e nitrogênio nas HS, principalmente nas frações HU e HA, e SM apresentou as menores concentrações em todas as frações. Nossos resultados mostram que manejos de solo com menor perturbação e remoção de resíduos promovem o aumento de carbono e nitrogênio em frações recalcitrantes, com concentração próxima às florestas nativas. A pastagem deve ser fertilizada para melhorar o estoque de carbono e nitrogênio recalcitrante, evitando o processo de degradação do solo tropical. Este é um resultado importante devido aos altos níveis de áreas degradadas no Brasil causadas pelo uso inadequado do solo, principalmente com pastagens.

PAlAVRAS-CHAVE: Pastagem de Brachiaria. Humina. Ácido fúlvico. Ácido húmico. Matéria orgânica

\section{REFERENCES}

AKPA, S. I.; ODEH, I. O.; BISHOP, T. F.; HARTEMINK, A. E.; AMAPU, I. Y. Total soil organic carbon and carbon sequestration potential in Nigeria. Geoderma, v. 271, p. 202-215, 2016.

https://doi.org/10.1016/j.geoderma.2016.0t2.021

ALMEIDA, R. F.; SILVEIRA, C. H.; MOTA, R. P.; MOITINHO, M.; ARRUDA, E. M.; MENDONÇA, E. S.; LA SCALA, N.; WENDLING, B. For how long does the quality and quantity of residues in the soil affect the carbon compartments and CO 2-C emissions?. Journal of soils and sediments, v. 16, n. 10, p. 2354-2364, 2016. https://doi.org/10.1007/s11368-016-1432-3

ALMEIDA, R. F.; MACHADO, H. A.; MARTINS, F. P.; DE SOUSA QUEIROZ, I. D.; TEIXEIRA, W. G.; MIKHAEL, J. E. R.; BORGES, E. N. Correlação do tamanho e da distribuição dos agregados em latossolos amarelo da região do Triângulo Mineiro com diferentes ambientes. Bioscience Journal, v. 30, n. 5, 2014. https://doi.org/10.14393/ufu.di.2018.705

DE ASSIS, C. P.; JUCKSCH, I.; DE SÁ MENDONÇA E.; NEVES, J. C. L. Carbono e nitrogênio em agregados de Latossolo submetido a diferentes sistemas de uso e manejo. Pesquisa Agropecuária Brasileira, v. 41, n. 10, p. 1541-1550, 2006. https://doi.org/10.1590/s0100-204x2006001000012

BLAIR, G. J.; LEFROY, R. D. B; LISLE, L. Soil carbon fractions based on their degree of oxidation, and the development of a carbon management index for agricultural systems. Australian journal of agricultural research, v. 46, n. 7, p. 1459-1466, 1995. https://doi.org/10.1071/ar9951459

COLETTO, A.F.; ALMEIDA, R.F.; MIKHAEL, J. E. R.; WENDLING, B.; CAMARGO, R. Chemical attributes of soil fertirrigated with biodigester effluent of swine origin. Australian Journal of Crop Science, v. 9, n. 5, p. 431, 2015.

CUNHA, T. J. F.; MACEDO, J. R.; RIBEIRO, L. P.; PALMIERI, F.; DE FREITAS, P. L.; AGUIAR, A. D. C. Impacto do manejo convencional sobre propriedades físicas e substâncias húmicas de solos sob Cerrado.

Revista Ciencia Rural, Santa Maria, v. 31, n. 1, p. 27-36, 2001. https://doi.org/10.1590/s010384782001000100005

Cunha, E. Q.; Stone, L. F.; Ferreira, E. P. B.; Didonet, A. D.; Moreira, J. A. A. Atributos físicos, químicos e biológicos de solo sob produção orgânica impactados por sistemas de cultivo. Revista Brasileira Engenharia Agrícola e Ambiental, v. 16, n. 1, p. 56-63, 2012. https://doi.org/10.1590/s1415-43662012000100008 
Recalcitrant carbon and nitrogen...

MIKHAEL, J. E. R. et al.

SOLOS, Embrapa. Sistema brasileiro de classificação de solos. Centro Nacional de Pesquisa de Solos: Rio de Janeiro, pp.412, 2006. https://doi.org/10.17138/tgft(1)121-122

FONTANA, A.; PEREIRA, M. G.; LOSS, A.; CUNHA, T. J. F.; SALTON, J. C. Atributos de fertilidade e frações húmicas de um Latossolo Vermelho no Cerrado. Pesquisa Agropecuária Brasileira, v. 41, n. 5, p. 847-853, 2006. https://doi.org/10.1590/s0100-204x2006000500018

GARRATT, M. P. D.; BOMMARCO, R.; KLEIJN, D.; MARTIN, E.; MORTIMER, S. R.; REDLICH, S.; SENAPATHI, D.; STEFFAN-DEWENTER, I.; ŚWITEK, S.; TAKACS, V.; VAN GILS, S.; VAN DER PUTTEN, W. H.; POTTS, S. G. Enhancing soil organic matter as a route to the ecological intensification of European arable systems. Ecosystems, p. 1-12, 2018. https://doi.org/10.1007/s10021-018-0228-2

HAYES, M. H. B.; MAC, P.; CARTHY, R. L.; MALCOLM, S. R. S. The search for structure: setting the scene. Humic substances II: In search of structure, p. 3-31, 1989.

JAKELAITIS, A.; SILVA, A. A.; SANTOS, A. A.; VIVIAN, R. Qualidade da camada superficial de solo sob mata, pastagens e áreas cultivadas. Pesquisa Agropecuária Tropical (Agricultural Research in the Tropics), p. 118-127, 2008.

JANTALIA, C. P.; RESCK, D.V.S.; ALVES, B.J.R.; ZOTARELLI, L.; URUQUIAGA, S.; BODDEY, R. Tillage effect on $\mathrm{C}$ stocks of a clayey Oxisol under a soybean-based crop rotation in the Brazilian Cerrado region. Soil and Tillage Research, v. 95, n. 1-2, p. 97-109, 2007. https://doi.org/10.1016/j.still.2006.11.005

LEITE, L.F.C.; MENDONÇA, E.D.S.; MACHADO, O.L.O.D.A.; MOTAS, E.S. Total C and N storage and organic C pools of a Red-Yellow Podzolic under conventional and no tillage at the Atlantic Forest Zone, southeastern Brazil. Soil Research, v. 41, n. 4, p. 717-730, 2003. https://doi.org/10.1071/sr02037

MARTINS, E.L.; CORINGA, J.E.S.; WEBER, O.L.S. Carbono orgânico nas frações granulométricas e substâncias húmicas de um Latossolo Vermelho Amarelo distrófico-LVAd sob diferentes agrossistemas. Acta amazônica, v. 39, n. 3, p. 655-60, 2009. https://doi.org/10.1590/s0044-59672009000300021

MARTINS, C.M.; COSTA, L.M.; SCHAEFER, C.E.G.R.; SOARES, E.M.B.; SANTOS, S.R. Frações da matéria orgânica em solos sob formações deciduais no norte de Minas Gerais. Revista Caatinga, v. 28, n. 4, p. 10-20, 2015. https://doi.org/10.1590/1983-21252015v28n402rc

NEUFELDT, H.; RESCK, D.V.S.; AYARZA, M.A. Texture and land-use effects on soil organic matter in Cerrado Oxisols, Central Brazil. Geoderma, v. 107, n. 3-4, p. 151-164, 2002. https://doi.org/10.1016/s00167061(01)00145-8

PAN, G.; SMITH, P.; PAN, W. The role of soil organic matter in maintaining the productivity and yield stability of cereals in China. Agriculture, Ecosystems \& Environment, v. 129, n. 1-3, p. 344-348, 2009. https://doi.org/10.1016/j.agee.2008.10.008

PANETTIERI, M.; RUMPEL, C.; DIGNAC, M. F.; CHABBI, A. Does grassland introduction into cropping cycles affect carbon dynamics through changes of allocation of soil organic matter within aggregate fractions?. Science of the Total Environment, v. 576, p. 251-263, 2017. https://doi.org/10.1016/j.scitotenv.2016.10.073

PICCOLO, A.; SPACCINI, R.; COZZOLINO, V.; NUZZO, A.; DROSOS, M.; ZAVATTARO, L.; TREVISAN, M. Effective carbon sequestration in Italian agricultural soils by in situ polymerization of soil organic matter under biomimetic photocatalysis. Land degradation \& development, v. 29, n. 3, p. 485-494, 2018. https://doi.org/10.1002/ldr.2877 
Recalcitrant carbon and nitrogen...

MIKHAEL, J. E. R. et al.

PÔRTO, M.L.; ALVES, J.C.; DINIZ, A.A.; SOUZA, A.P.; SANTOS, D. Indicadores biológicos de qualidade do solo em diferentes sistemas de uso no Brejo Paraibano. Ciência e Agrotecnologia, v. 33, n. 4, p. 1011-1017, 2009. https://doi.org/10.1590/s1413-70542009000400010

PULROLNIK, J.; BARROS, N.F.; SILVA, I.R.; NOVAIS, R.F.; BRANDANI, C.B. Estoques de carbono e nitrogênio em frações lábeis e estáveis da matéria orgânica de solos sob eucalipto, pastagem e cerrado no Vale do Jequitinhonha-MG. Revista Brasileira de Ciência do Solo, Viçosa, v. 33, n. 5, p. 1125-1136, 2009. https://doi.org/10.1590/s0100-06832009000500006

ROSSI, C.Q.; PEREIRA, M.G.; GIACOMO, S.G.; BETTA, M.; POLIDORO, J.C. Frações húmicas da matéria orgânica do solo cultivado com soja sobre palhada de braquiária e sorgo. Bragantia, Campinas, v. 70, n. 3, p. 622-630, 2011. https://doi.org/10.1590/s0006-87052011000300018

SALTON, J.C.; MIELNICZUK, J.; BAYER, C.; FABRÍCIO, A.C.; MACEDO, M.C.M.; BROCH, D.L. Teor e dinâmica do carbono no solo em sistemas de integração lavoura-pecuária. Pesquisa agropecuaria brasileira, Brasília, v. 46, n. 10, p. 1349-1356, 2011. https://doi.org/10.1590/s0100-204x2011001000031

SÁNCHEZ-GONZÁLEZ, A.; CHAPELA-LARA, M.; GERMÁN-VENEGAS, E.; FUENTES-GARCÍA, R.; RÍO-PORTILLA, F.; SIEBE, C. Changes in quality and quantity of soil organic matter stocks resulting from wastewater irrigation in formerly forested land. Geoderma, v. 306, p. 99-107, 2017.

https://doi.org/10.1016/j.geoderma.2017.07.009

SANTANA, G.S.; DICK, D.P.; JACQUES, A.V.A.; CHITARRA, G.S. Substâncias húmicas e suas interações com Fe e Al em Latossolo subtropical sob diferentes sistemas de manejo de pastagem. Revista Brasileira de Ciência do Solo, Viçosa, v. 35, n. 2, p. 461-472, 2011. https://doi.org/10.1590/s0100-06832011000200015

SILVA, M.P.; ARF, O.; SÁ, M.E.; ABRANTES, F.L.; BERTI, C.L.F.; SOUZA, L.C.D.; ARRUDA, N. Palhada, teores de nutrientes e cobertura do solo por plantas de cobertura semeadas no verão para semeadura direta de feijão. Agrarian, Dourados, v. 7, n. 24, p. 233-243, 2014.

SIX, J.; CONANT, R.T.; PAUL, E.A.; PAUSTIAN, K. Stabilization mechanisms of soil organic matter: implications for C-saturation of soils. Plant and soil, v. 241, n. 2, p. 155-176, 2002.

https://doi.org/10.1023/a:1016125726789

SMITH, P.; LUTFALLA, S.; RILEY, W. J.; TORN, M. S.; SCHMIDT, M. W. I.; SOUSSANA, J. F. The changing faces of soil organic matter research. European journal of soil science, v. 69, n. 1, p. 23-30, 2018. https://doi.org/10.1111/ejss.12500

SMITH, Pete. Soils and climate change. Current opinion in environmental sustainability, v. 4, n. 5, p. 539544, 2012.

STEVENSON, Frank J. Humus chemistry: genesis, composition, reactions. John Wiley \& Sons, 1994.

STEVENSON, F. J. Extraction, fractionation, and general chemical composition of soil organic matter. Humus chemistry. Genesis, composition, reactions, 1982.

TEDESCO, M. J.; GIANELLO, C.; BISSANI, C. A.; BOHNEN, H.; VOLKWEISS, S. J. Análise de solo, plantas e outros materiais. Porto Alegre, Universidade Federal do Rio Grande do Sul, 1995. 174p. Boletim técnico, v. 5.

SOLLINS, P.; GREGG, J. W. Soil organic matter accumulation in relation to changing soil volume, mass, and structure: concepts and calculations. Geoderma, v. 301, p. 60-71, 2017.

https://doi.org/10.1016/j.geoderma.2017.04.013 
STOCKMANN, U.; ADAMS, M. A.; CRAWFORD, J. W.; FIELD, D. J.; HENAKAARCHCHI, N.; JENKINS, M.; MINASNY, B.; MCBRATNEY, A. B.; DE REMY DE COURCELLES, V.; SINGH, K.; WHEELER, I.; ABBOTT, L.; ANGERS, D. A.; BALDOCK, J.; BIRD, M.; BROOKES, P. C.; CHENU, C.; JASTROW, J. D.; LAL, R.; LEHMANN, J.; O'DONNELL, A. G.; PARTON, W. J.; WHITEHEAD, D.; ZIMMERMANN, M. The knowns, known unknowns and unknowns of sequestration of soil organic carbon. Agriculture, Ecosystems \& Environment, v. 164, p. 80-99, 2013.

https://doi.org/10.1016/j.agee.2012.10.001

TSIAFOULI, M.A.; THE`BAULT, E.; SGARDELIS, S.P.; DE RUITER, P.C.; VAN DER PUTTEN, W.H.; BIRKHOFER, K.; HEMERIK, L.; DE VRIES, F.T.; BARDGETT, R.D.; BRADY, M.V.; BJORNLUND, L.; JØRGENSEN, H.B.; CHRISTENSEN, S.; HERTEFELDT, T.D.; HOTES, S.; GERA HOL, W.H.; FROUZ J.; LIIRI, M.; MORTIMER, S.R.; SETA“LA“ „H.; TZANOPOULOS, J.; UTESENY, K.; PIZॅL, V.; STARY, J.; WOLTERS, V.; HEDLUND, K. Intensive agriculture reduces soil biodiversity across Europe. Global change biology, v. 21, n. 2, p. 973-985, 2015. https://doi.org/10.1111/gcb.12752

VERGUTZ, L.; NOVAIS, R.F.; SILVA, I.R.; BARROS, N.F.; NUNES, T.N.; PIAU, A.A.M. Mudanças na matéria orgânica do solo causadas pelo tempo de adoção de um sistema agrossilvopastoril com eucalipto. Revista Brasileira de Ciência do Solo, v. 34, n. 1, 2010. https://doi.org/10.1590/s010006832010000100005

VOLKOFF, B.; FLEXOR, J.M.; SANTA-ISABEL, L.M.; SANTA-ISABEL, M. Natureza do húmus nos Latossolos distróficos da Bahia. Revista Brasileira de Ciência do Solo, v. 2, n. 1, p. 59-63, 1978.

YEOMANS, J.C.; BREMNER, J.M. A rapid and precise method for routine determination of organic carbon in soil. Communications in soil science and plant analysis, v. 19, n. 13, p. 1467-1476, 1988.

https://doi.org/10.1080/00103628809368027

WENDLING, B.; SÁ, E.M.; VINHAL-FREITAS, I.C. Mudanças no carbono e nitrogênio em diferentes compartimentos da matéria orgânica sob sistema agrossilvipastoril. Ciência Florestal, v. 21, n. 4, p. 641-653, 2011. https://doi.org/10.5902/198050984509

ZINN, Y.L.; LAL, R.; RESCK, D.V.S. Eucalypt plantation effects on organic carbon and aggregation of three different-textured soils in Brazil. Soil Research, v. 49, n. 7, p. 614-624, 2011. https://doi.org/10.1071/sr11264 